Portland State University

PDXScholar

$5-24-2019$

\title{
Species Diversity in the Hypertragulid (Mammalia: Artiodactyla) Population of the John Day Basin, Oregon
}

Lana K. Jewell

Portland State University

Follow this and additional works at: https://pdxscholar.library.pdx.edu/honorstheses

Let us know how access to this document benefits you.

\section{Recommended Citation}

Jewell, Lana K., "Species Diversity in the Hypertragulid (Mammalia: Artiodactyla) Population of the John Day Basin, Oregon" (2019). University Honors Theses. Paper 718.

https://doi.org/10.15760/honors.735

This Thesis is brought to you for free and open access. It has been accepted for inclusion in University Honors Theses by an authorized administrator of PDXScholar. Please contact us if we can make this document more accessible: pdxscholar@pdx.edu. 
Species Diversity in the Hypertragulid (Mammalia: Artiodactyla) Population of the John Day Basin, Oregon

\author{
by \\ Lana Jewell \\ An undergraduate honors thesis submitted in partial fulfillment of the \\ requirements for the degree of \\ Bachelor of Science \\ in \\ University Honors \\ and
}

Geology

Thesis Advisers:

Dr. Nicholas Famoso and Dr. Ashley Streig

Portland State University 


\begin{abstract}
Members of the family Hypertragulidae (order Artiodactyla, class Mammalia) are the most abundant mammals in the Turtle Cove Member (Oligocene) of the John Day Formation, located in central and eastern Oregon, and make up about $40 \%$ of the preserved specimens of the John Day Basin. Three species and two separate genera are described in the area, but any preexisting research lacks statistical support for this level of variation. Species designation among extinct artiodactyls is predominantly based on morphological and morphometric examination of dentition, but studies conducted with extant artiodactyls have revealed that this may not be a reliable diagnostic technique. Other research introduces the possibility of postcranial morphology as indicative of species, but this is not successful in all artiodactyl families. Given these two possible metrics, I use coefficients of variation $(V)$ on dental measurements and astragali measurements of hypertragulid specimens designated Hypertragulus hesperius, Hypertragulus minutus, and Nanotragulus planiceps as a metric for determining if there is more than one species present in the population. Both the asymptotic $V$ equality test and the modified signed-likelihood ratio $V$ equality test show that $V$ values of anterior-posterior molar length (APL) and transverse molar width (TW) vary significantly when comparing single species of modern ecological analogs (Muntiacus muntjak, Muntiacus reevesi, and Tragulus javanicus) to groupings at the genus level. However, the $V$ equality tests on dental and postcranial measurements yield almost no significant results when comparing variation in the extinct John Day hypertragulid population to an extant population comprised of a single species. The low level of variation in the hypertragulids statistically supports the hypothesis that there is only one species present in the population, which suggests over-splitting of the species in the John Day Basin.
\end{abstract}

\title{
INTRODUCTION
}

Members of the family Hypertragulidae (order Artiodactyla, class Mammalia) are the single most abundant mammals in the Turtle Cove Member of the John Day Formation of central and eastern Oregon and make up almost 1,500 of the preserved specimens of the John Day Basinabout $40 \%$ of the total collection (Famoso, 2014). While there have been three species of hypertragulids identified in the John Day Basin, there has been no prior statistical analysis of variation in the population to determine if this specific division is accurate. To conduct a 
paleoecological analysis of hypertragulids within the John Day area, the number of verifiable species present must first be determined. This project aims to determine the species-level variation in hypertragulid specimens present in the John Day Basin and whether both dental and postcranial measurements reflect the same amount of variation in the population.

\section{BACKGROUND}

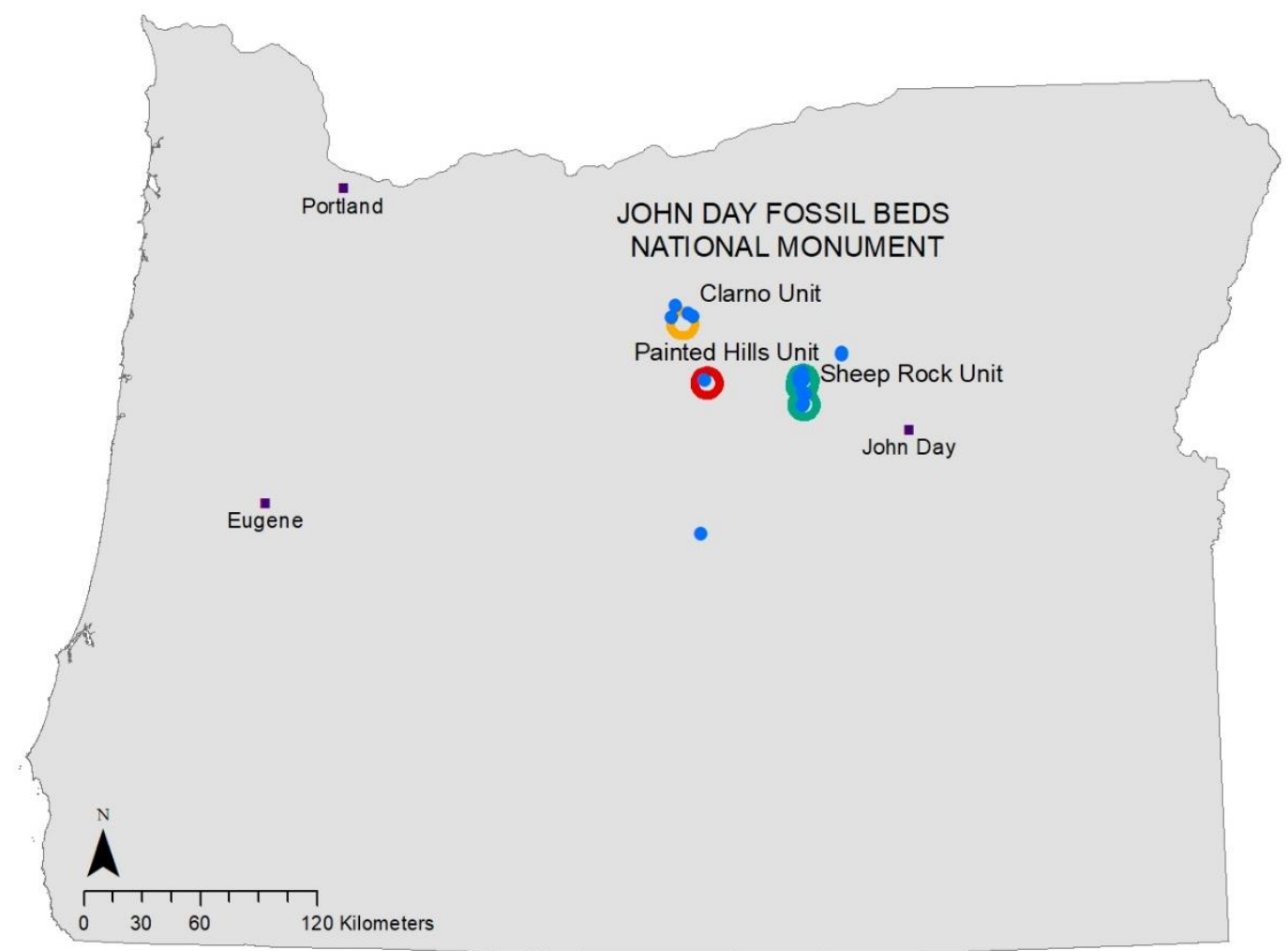

Figure 1. Localities of hypertragulid specimens (blue) in the John Day Basin, with units of the John Day Fossil Beds National Monument and nearby cities..

The extinct Family Hypertragulidae consisted of small basal ruminant artiodactyls known for their lack of horns and distinct tusklike canines (Métais \& Vislobokova, 2007). The extant taxa most closely related to this family are the tragulids (Tragulus sp.), also known as chevrotains or mouse-deer, which can serve as a modern phylogenetic and ecological analog for hypertragulids. Hypertragulids likely lived in similar forested habitats and consumed mixed foraging and browsing diets (Métais \& Vislobokova, 2007) similar to the tragulids, as well as the modern muntjac (Muntiacus sp.). Hypertragulids were widespread across North America from the late 
middle Eocene to the early Miocene, which corresponds to the Duchnesean (40.5 Ma) to late Arikareean (21 Ma) North American Land Mammal Ages (Métais \& Vislobokova, 2007). In the John Day region (Figure 1), there have been three species identified to date-Hypertragulus hesperius (Hay, 1902), Nanotragulus (= Allomeryx) planiceps (Sinclair, 1905), and Hypertragulus minutus (Lull, 1922).

Hypertragulid specimens are preserved in the Turtle Cove, Kimberly, and Haystack Valley members of the John Day Formation (Tedford et. al., 2004; Woodburne, 2004; Famoso, 2018). While there has been little research into the John Day hypertragulids, previous work done in the White River Group of Badlands National Park in South Dakota clarifies morphometric and phylogenetic distinctions among species (Gardner, 2015. While this work has found distinguishable characters between $H$. minutus and $N$. planiceps, there has been no confirmed discrepancy between $H$. hesperius and other species of Hypertragulidae. This uncertainty, amid other discussions of phylogenetics in Hypertragulidae (Webb \& Taylor, 1980; Vislobokova, 2001; Métais \& Vislobokova, 2007), provides sufficient reason to closely examine the population and the statistical variation between species. While a phylogenetic analysis is outside the scope of this project, this work will set a foundation for further inspection of specimens, potentially leading to more fossils with associated species-level designations.

The most widely used method for determining species among extinct artiodactyls is examination of dental characters; both morphology and measurement. However, research conducted with modern artiodactyls has called into question the validity of dentition as a faultless diagnostic technique - populations of artiodactyls experience such uneven wear on their teeth that there is greater than average variation in dental measurements among same-species individuals (EmeryWetherell \& Davis, 2018). Recently, there has been increased interest in the possibility of postcranial characters as a diagnostic on fine taxonomic scales (DeGusta \& Vrba, 2003; Davis \& Calède, 2012; Davis \& McHorse, 2013). While this has not yet been successful in all families, there is potential that astragali could function as a second diagnostic character to support the primary analysis of dentition in Hypertragulidae (Métais \& Vislobokova, 2007). 


\section{HYPOTHESES}

$\mathrm{H}_{0}$ : There is no variation in the dental and postcranial measurements to support separate taxa, and there is only one hypertragulid within the John Day Basin.

$\mathrm{H}_{1}$ : There is enough substantiated variation in both the dental and post-cranial measurements to support two separate hypertraguline taxa, but there is not enough support of either dental or postcranial measurements to classify three taxa.

$\mathrm{H}_{2}$ : Both the dental and post-cranial specimens show enough variation to substantiate the presence of three taxa in the John Day Basin, namely Hypertragulus hesperius, H. minutus, and Nanotragulus planiceps.

\section{METHODS}

\section{Dentition}

I examined the collection of hypertragulid material from John Day Fossil Beds National Monument (JODA), Kimberly, OR (Figure 1). The majority of the hypertragulid specimens in the JODA collection are teeth, but there is also a great deal of postcranial material. To determine species-level variation in dentition, I measured the anterior-posterior length (APL) and transverse width (TW) of both upper and lower molars, as shown in Figure 2. Specimens were only chosen when tooth position could be determined (i.e. if the molar is the first, second or third molar in the tooth row). This sample group included molars from maxillae, dentaries, and isolated teeth. All measurements were taken in millimeters using Mitutoyo 4" digital calipers (instrumental error is $\pm 0.02 \mathrm{~mm}$ ). To maintain consistency, APL was measured along the buccal side of upper molars and along the lingual side of lower molars. I also took care to measure APL at the base of the tooth, at the enamel-dentine junction, to reduce variation from wear and wear-stage. TW was measured at widest width on each individual tooth. I am limiting my analysis to fossils found in the Turtle Cove Member of the John Day Formation, but one could also apply similar techniques to specimens found in the other members for a broader study.

All statistical analysis was conducted in R version 3.5.1 (R Core Team, 2018), with use of the packages dplyr (Version 0.7.8, Wickham et. al., 2016), ggfortify (Version 0.4.5, Tang, Horikoshi, \& Li, 2016), and cvequality (Version 0.1.3; Marwick \& Krishnamoorthy, 2019). 

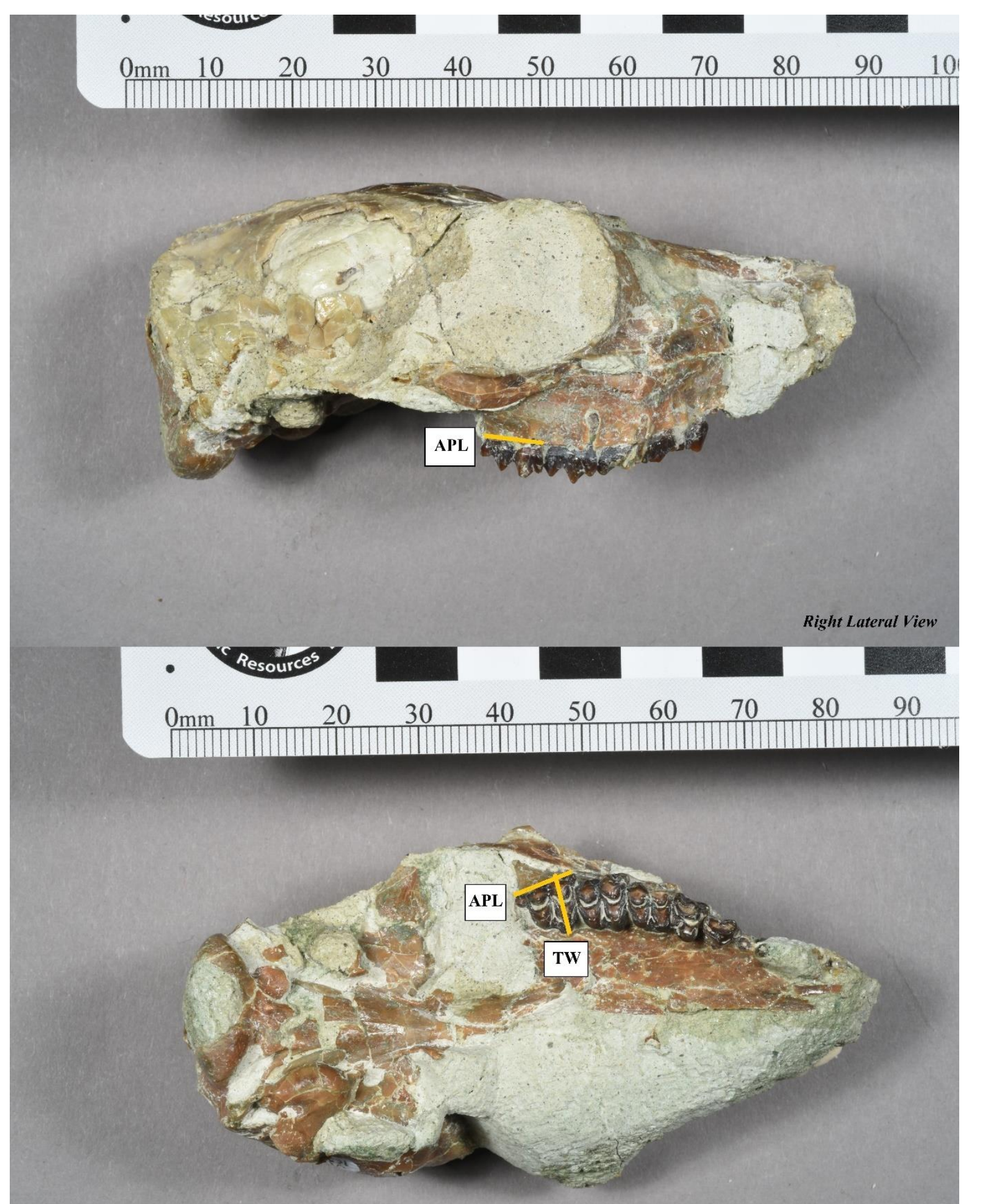

Ventral View

Figure 2. Anterior-posterior length (APL) and transverse width (TW) measurements, shown on a Hypertragulus hesperius skull (JODA 16548). Top image shows APL taken along the enamel-dentine junction from the right lateral view. Bottom image shows $A P L$ and $T W$ from the ventral view. 


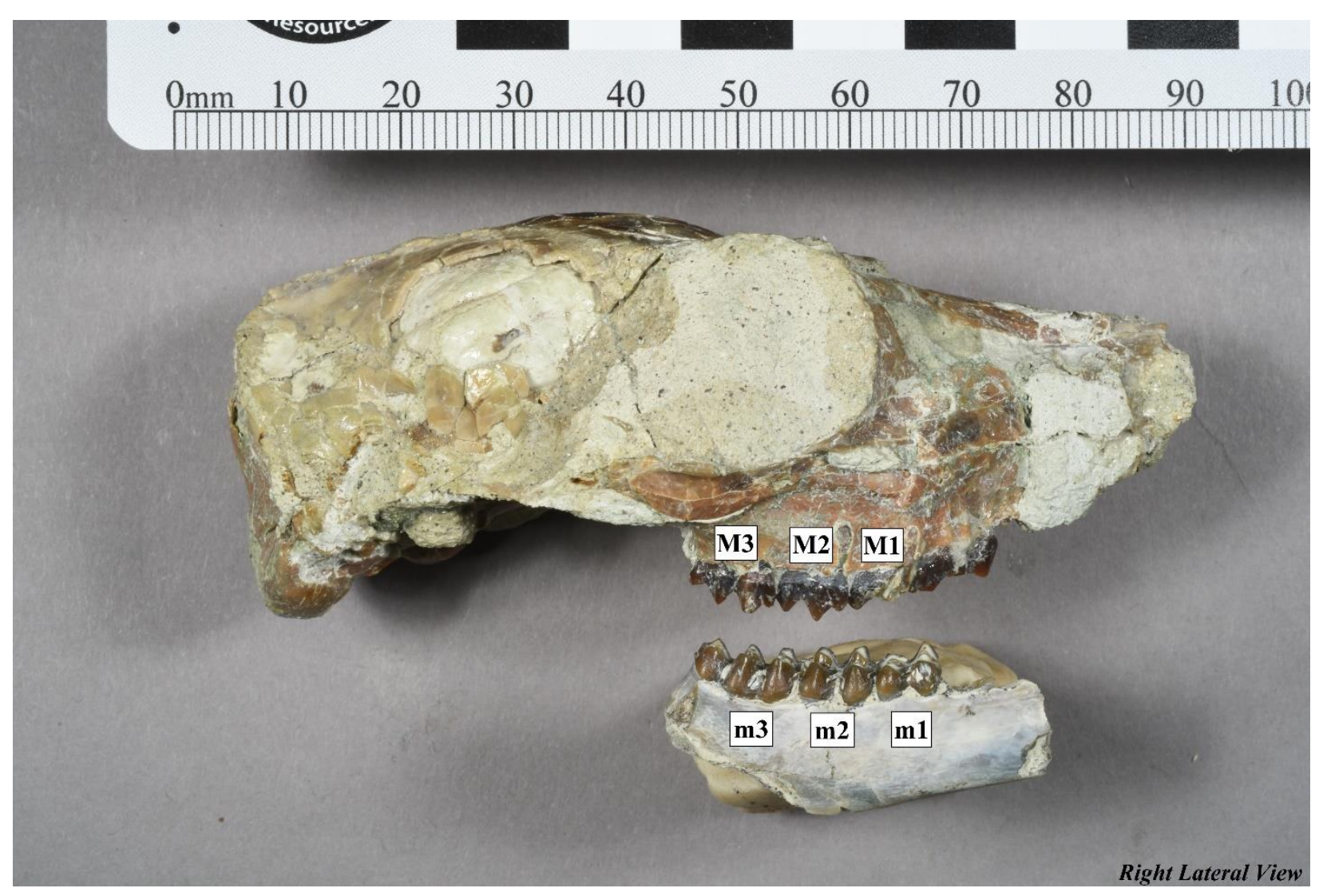

Figure 3. Lateral view of Hypertragulus hesperius skull (JODA 16548) and right dentary with tooth positions labeled. The six tooth positions are the upper molars on the maxilla (M1-M3) and the lower molars on the dentary (m1-m3).

After measuring teeth in all six tooth positions (Fig. 3), I conducted an Analysis of Variance (ANOVA) and a post-hoc Tukey Test (Fisher, 1928; Tukey, 1949; Hammer \& Harper, 2008; Famoso, 2018) on both the APL and TW data, to determine which specific molars differ significantly between individuals. I then calculated the coefficients of variation $(V)$ for the entire population of hypertragulids as shown in Equation 1, where $\mu$ is the mean and $\sigma$ is the standard deviation. The $V$ gives a percentage of variation in the entire population for a linear measurement, which is a previously established metric of identifying populations with more than one species present (Pearson, 1896; Simpson \& Roe, 1939; Cope \& Lacy, 1992; Famoso, 2017). For groups with a sample size smaller than $\mathrm{n}=5$, I used a small-sample correction (Sokal \& Braumann, 1980) shown in Equation 2 .

$$
\begin{array}{r}
V=\frac{\sigma}{\mu} * 100 \\
V=\frac{\sigma}{\mu} *\left(1+\frac{1}{4 * n}\right) * 100
\end{array}
$$


I compared measurements of upper molars of the fossil hypertragulids to the modern southern red muntjac, Muntiacus muntjak, using data from Emery-Wetherell \& Davis (2018). I compared the lower molars to modern M. muntjak, Muntjack. reevesi (Reeve's muntjac), and Tragulus javanicus (Java mouse-deer) using data provided by C. Janis (Janis, 1990; Janis, personal communication, February $\left.14^{\text {th }} 2019\right)$. M. muntjak and M. reevesi have similar morphologies and dietary habits to the extinct hypertragulids making them excellent ecomorphs. T. javanicus is among the most closely related taxa to the Hypertragulidae, and therefore serves as a phylogenetic analog to the hypertragulids. I used both asymptotic (Feltz \& Miller, 1996) and modified signed likelihood ratio tests (Krishnamoorthy \& Lee, 2014) as part of the 'cvequality' R package to compare the $V$ values of all analyzed populations. To determine how well the $V$ equality tests can compare the ancient and modern populations of basal ruminants, I used these tests to compare lower molars of modern species amongst each other. I sorted the modern analogs into groups: one total 'population' comprised of all three species, another made up of the two species in the genus Muntiacus, and each of the single species populations. I compared these groups to each other, expecting to find the highest variation in the total population, followed by the Muntiacus group, and followed by the individual species having the lowest level of variation. The $V$ values should vary significantly amongst these groups, with statistical significance denoted by a $p$-value $\leq 0.05$ (Fisher, 1928). Given that the John Day Basin hypertragulid population is stated to have three separate species belonging to two genera, I expect the $V$ values of the hypertragulid population to be similarly high to those of the combined extant population and significantly higher than that of a single extant species. The resulting $p$-values from each test will indicate if the variation within groups of hypertragulids is significantly different than what is expected for a single-species population, which would then substantiate the alternate hypotheses that there is more than one species present in the John Day Basin. If the $V$ test value is not significantly different between the modern analog and the hypertragulids, then the null hypothesis of only one species will be supported. 
Astragali

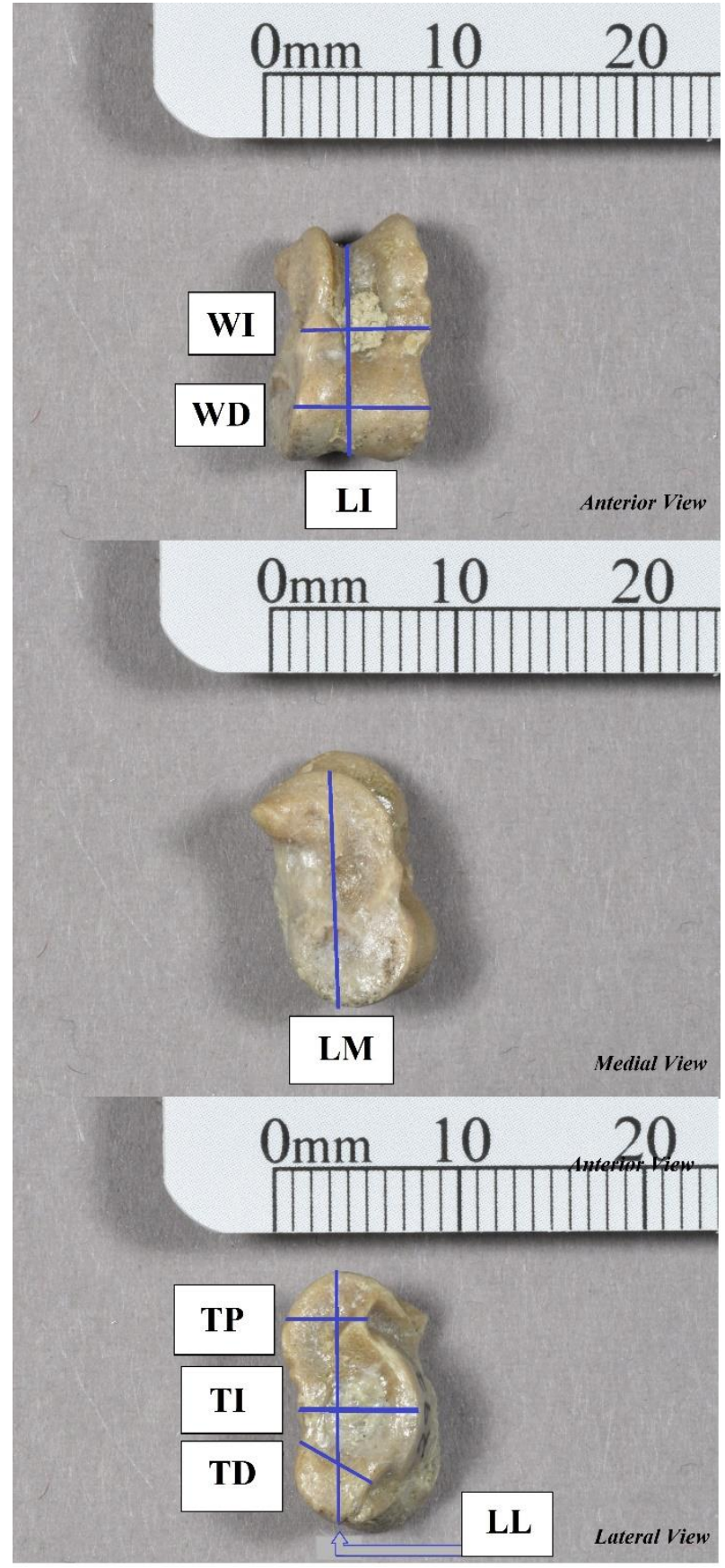

measured high-quality photographs of eight $T$.

javanicus specimens from the Museum of

Comparative Zoology (MCZ) Harvard

Vertebrate Collection, located in Cambridge,

Massachusetts, using ImageJ (Schneider,
To corroborate the analysis from the dental characters, I measured astragali of the hypertragulids. Astragali (ankle bones) are a postcranial element which are useful as a measure of body size (Davis \& Calède, 2012; Davis \& McHorse, 2013). Eight measurements of astragali are needed for analysis, as per DeGusta \& Vrba (2003) and illustrated in Figure 4: medial length (LM), intermediate length (LI), lateral length (LL), distal thickness (TD), intermediate thickness (TI), proximal thickness (TP), distal width (WD), and intermediate width (WI). I then used a Principal Components Analysis (PCA) to determine which of these measurements covary, and which are significant for analysis (Davis \& Calède, 2012; Davis \& McHorse, 2013). While there are fewer postcranial specimens with species-level identification, I still calculated $V$ values and performed $V$ equality tests to compare the number of species inferred from the dental measurements. I compared measured astragali dimensions of hypertragulids to the same measurements of $T$. javanicus astragali. I

Figure 4. Photo of JODA 2920, hypertragulid astragalus, or ankle bone. Top image shows anterior view, with intermediate length (LI), intermediate width (WI), and distal width (WD) measurements. Middle image shows medial view with medial length (LM) measurement. Bottom image shows lateral view with lateral length (LL), proximal thickness (TP), intermediate thickness (TI), and distal thickness (TD) measurements. 
Rasband, \& Eliceiri, 2012). $V$ values were calculated and compared as previously described for dentition, but given lack of data on other modern analogs and limited sample sizes of $H$. minutus and $N$. planiceps specimens, the primary analysis was conducted by comparison of the entire hypertragulid population to that of the modern $T$. javanicus specimens.

\section{RESULTS}

\section{Extant Analog Dentition}

$V$ values calculated for lower first molars of the modern analogs are presented in Table 1 . The $V$ equality tests, the asymptotic test (AT) and the modified signed-likelihood ratio test (MSLRT), both show a significant level in variation of lower molars when comparing multiple species of ecologic analogs and related taxa together, as presented in Table 2. The difference in variation is significant for both the APL (AT $p=0.000345$, MSLRT $p=0.0000797$ ) and TW (AT $p=$ 0.0000105, MSLRT $p=0.00000107$ ) when distinguishing between the total population of modern analogs (two species of modern Muntiacus (M. muntjak and M. reevesi) and one species of T. javanicus), as compared to a population of the Muntiacus species and a population of only Tragulus specimens. The $V$ equality tests varied between the APL and the TW when comparing two Muntiacus species together compared to only one of the tested Muntiacus species. There was no significantly different level of variation in the APL (AT $p=0.154$, MSLRT $p=0.125$ ), but the TW did show significant variation (AT $p=0.025$, MSLRT $p=0.019$ ), However, both tests did have significant $p$-values for the APL (AT $p=0.027$, MSLRT $p=0.024$ ) and the TW (AT $p$ $=0.025$, MSLRT $p=0.014$ ) when comparing the two Muntiacus species to the single species of Tragulus.

Table 1. V values for lower first molars of modern analog taxa

\begin{tabular}{|l|l|l|}
\hline & m1 APL & $\mathrm{m} 1 \mathrm{TW}$ \\
\hline Combined modern analog $V$ & 28.346081 & 32.063406 \\
\hline Muntiacus sp. $V$ & 14.242417 & 12.444297 \\
\hline M. muntjak $V$ & 8.440777 & 5.065173 \\
\hline M. reevesi $V$ & 9.843680 & 10.543084 \\
\hline T. javanicus $V$ & 5.857791 & 5.059644 \\
\hline
\end{tabular}


Table 2. V equality tests for different groupings of modern analogs, both asymptotic test and modified signed likelihood ratio test (SLRT). Bold p-value denotes significant difference in $V$ values, where $p<0.05$.

\begin{tabular}{|l|l|l|l|l|}
\hline & \multicolumn{2}{|c|}{ m1 APL } & \multicolumn{2}{c|}{ m1 TW } \\
\hline & $\begin{array}{l}\text { Asymptotic } \\
p \text {-value }\end{array}$ & $\begin{array}{l}\text { Modified SLRT } \\
p \text {-value }\end{array}$ & $\begin{array}{l}\text { Asymptotic } \\
p \text {-value }\end{array}$ & $\begin{array}{l}\text { Modified SLRT } \\
p \text {-value }\end{array}$ \\
\hline $\begin{array}{l}\text { Total pop + Muntiacus sp. } \\
+ \text { T. javanicus }\end{array}$ & $\mathbf{0 . 0 0 0 3 4 4 9 9 6 5}$ & $\mathbf{0 . 0 0 0 0 5 9 2 8 5 2 6}$ & $\mathbf{0 . 0 0 0 0 1 0 4 8 5 4 5}$ & $\mathbf{0 . 0 0 0 0 0 1 0 6 8 1 1 9}$ \\
\hline $\begin{array}{l}\text { Muntiacus } \text { sp. }+ \\
\text { M. } \text { muntjak }\end{array}$ & 0.1543812368 & 0.1251785 & $\mathbf{0 . 0 2 5 3 9 1 4 3}$ & $\mathbf{0 . 0 1 9 4 9 8 9 5}$ \\
\hline $\begin{array}{l}\text { Muntiacus } \mathrm{sp} .+ \\
\text { T. } \text { javanicus }\end{array}$ & $\mathbf{0 . 0 2 7 1 9 6 1 1 7 1}$ & $\mathbf{0 . 0 2 4 0 4 7 4 9}$ & $\mathbf{0 . 0 2 5 2 5 5 8 1}$ & $\mathbf{0 . 0 1 3 8 8 9 5 7}$ \\
\hline
\end{tabular}

\begin{tabular}{|l|l|l|l|l|}
\hline & \multicolumn{2}{|c|}{$\mathrm{m} 2$ APL } & \multicolumn{2}{c|}{$\mathrm{m} 2 \mathrm{TW}$} \\
\hline & $\begin{array}{l}\text { Asymptotic } \\
p \text {-value }\end{array}$ & $\begin{array}{l}\text { Modified SLRT } \\
p \text {-value }\end{array}$ & $\begin{array}{l}\text { Asymptotic } \\
p \text {-value }\end{array}$ & $\begin{array}{l}\text { Modified SLRT } \\
p \text {-value }\end{array}$ \\
\hline $\begin{array}{l}\text { Total pop }+ \text { Muntiacus } \mathrm{sp} . \\
+ \text { T. } \text { javanicus }\end{array}$ & $\mathbf{0 . 0 0 0 5 2 0 1 6 6 5}$ & $\mathbf{0 . 0 0 0 0 2 3 9 4 1 2 9}$ & $\mathbf{0 . 0 0 0 0 1 9 2 9 3 1 7}$ & $\mathbf{0 . 0 0 0 0 0 4 1 4 7 8 5 2}$ \\
\hline $\begin{array}{l}\text { Muntiacus } \text { sp. }+ \\
\text { M. } \text { muntjak }\end{array}$ & 0.6849871822 & 0.632067 & $\mathbf{0 . 0 4 8 2 4 4 6 7}$ & 0.03734388 \\
\hline $\begin{array}{l}\text { Muntiacus } \text { sp. }+ \\
\text { T. } \text { javanicus }\end{array}$ & $\mathbf{0 . 0 0 8 4 8 6 2 2 3 0}$ & $\mathbf{0 . 0 0 2 4 8 5 9 2 2}$ & 0.1108129 & 0.09272634 \\
\hline
\end{tabular}

\begin{tabular}{|l|l|l|l|l|}
\hline & \multicolumn{2}{|c|}{ M2 APL } & \multicolumn{2}{c|}{ M2 TW } \\
\hline & $\begin{array}{l}\text { Asymptotic } \\
p \text {-value }\end{array}$ & $\begin{array}{l}\text { Modified SLRT } \\
p \text {-value }\end{array}$ & $\begin{array}{l}\text { Asymptotic } \\
p \text {-value }\end{array}$ & $\begin{array}{l}\text { Modified SLRT } \\
p \text {-value }\end{array}$ \\
\hline $\begin{array}{l}\text { Total pop + Muntiacus } \text { sp. } \\
+ \text { T. } \text { javanicus }\end{array}$ & $\mathbf{0 . 0 0 0 4 8 6 0 5 8 4}$ & $\mathbf{0 . 0 0 0 3 4 9 1 2 4 6}$ & $\mathbf{0 . 0 0 0 3 8 2 9 6 6 8}$ & $\mathbf{0 . 0 0 0 3 1 5 4 1 5 7}$ \\
\hline $\begin{array}{l}\text { Muntiacus } \text { sp. }+ \\
\text { M. } \text { muntjak }\end{array}$ & 0.6251837576 & 0.5547034290 & 0.5026901915 & 0.4375754255 \\
\hline $\begin{array}{l}\text { Muntiacus } \text { sp. }+ \\
\text { T. javanicus }\end{array}$ & 0.7792352902 & 0.7807018776 & 0.9643010143 & 1.0000000000 \\
\hline
\end{tabular}

\section{Hypertragulid Dentition}

The ANOVA and post-hoc Tukey test showed a statistically significant difference in measurements of APL of the first and the third tooth position, as well as a difference in TW of 
the upper and lower molars, as seen in Figures 5 and 6. Given this, I focused my analysis on the upper and lower molars in the first and third tooth positions.

$V$ values of the upper and lower first molars for the combined Hypertragulidae population, $H$. hesperius, H. minutus, and $N$. planiceps are presented in Table 3 as well as the $p$-values from the $V$ equality tests. The modified SLRT test showed significant variation between the total population and the three individual species in one case, the m3 APL, where the $p$-value was slightly below the designated threshold of $0.05(p=0.041)$. All other $V$ equality tests (both asymptotic and modified SLRT) for upper and lower first molars were not significant when comparing variation from the species groups to the total hypertragulid population. Figure 7 shows $V$ values for these taxa in addition to $V$ values of the modern analogs presented in Table 1 .

Table 4 contains $V$ values for the upper and lower first and third molars of both the total hypertragulid population and the modern M. muntjak population, and the associated $p$-values for the $V$ equality tests. For these eight total dimensions, only the m3 APL measurement is significantly different (AT $p=0.022$, MSLRT $p=0.008$ ) from the entire fossil population to the single modern species.

Table 3. V values and resulting V equality p-values for first molars of hypertragulids. Bold pvalue denotes significant difference in $V$ values, where $p<0.05$.

\begin{tabular}{|l|l|l|l|l|}
\hline & M1 APL & m1 APL & M1 TW & m1 TW \\
\hline Hypertragulid population $V$ & 11.51817664 & 11.2226980 & 11.8304483 & 8.3699800 \\
\hline H. hesperius $V$ & 11.35982404 & 9.2223921 & 10.0620888 & 7.6646850 \\
\hline H. minutus $V$ & 8.89803094 & 16.5717275 & 10.9235310 & 9.4735571 \\
\hline N. planiceps $V$ & 2.28762388 & 16.6905915 & 6.2604599 & 1.2306002 \\
\hline Asymptotic $p$-value & 0.25163408 & 0.5460764 & 0.4515642 & 0.5174573 \\
\hline Modified SLRT $p$-value & $\mathbf{0 . 0 4 1 1 0 5 5 3}$ & 0.3924073 & 0.7124514 & 0.1914327 \\
\hline
\end{tabular}




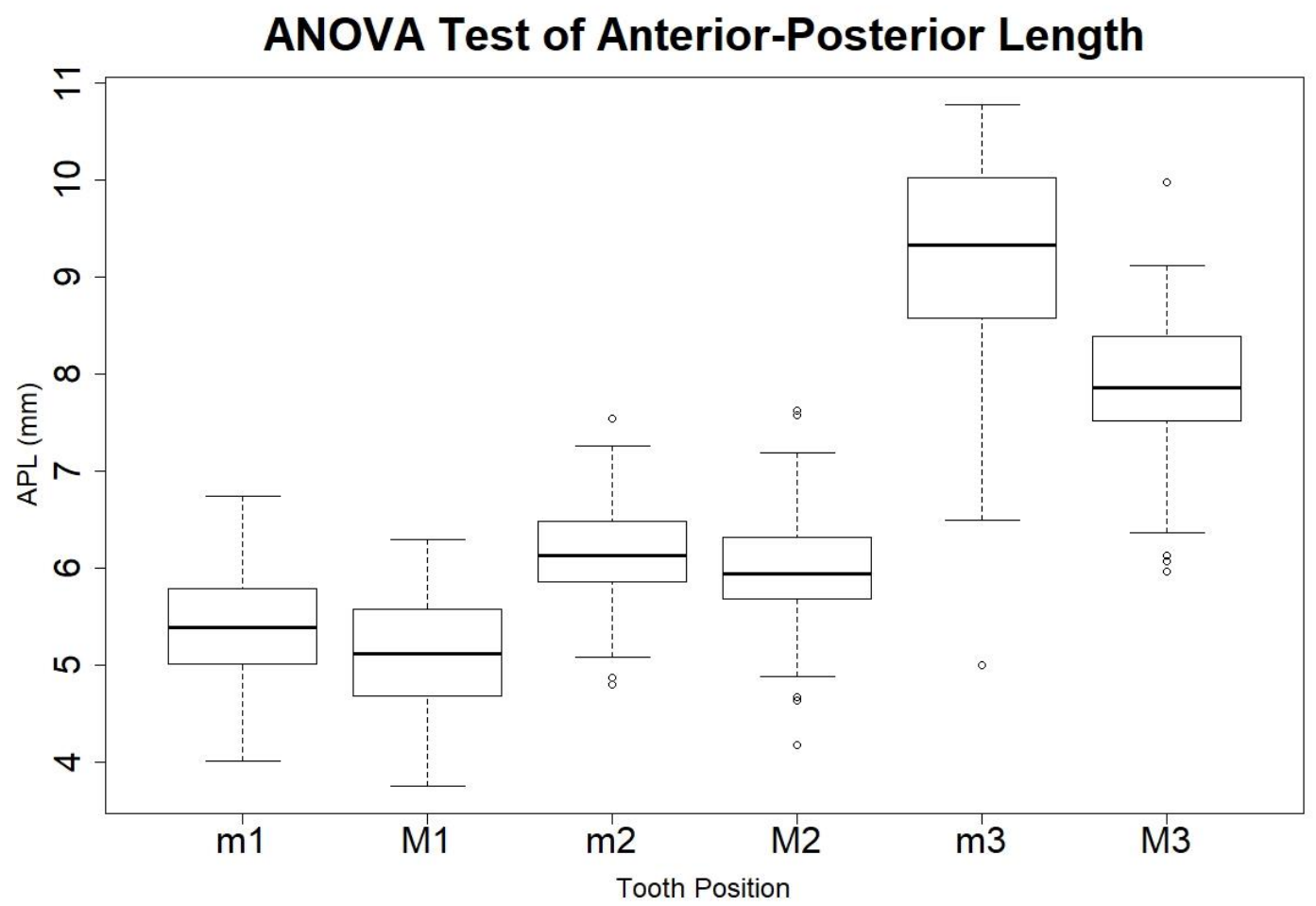

Figure 5. Boxplot of ANOVA results for APL of different tooth positions across all hypertragulids. APL is correlated by molar, with the upper and lower values for each molar overlapping significantly.

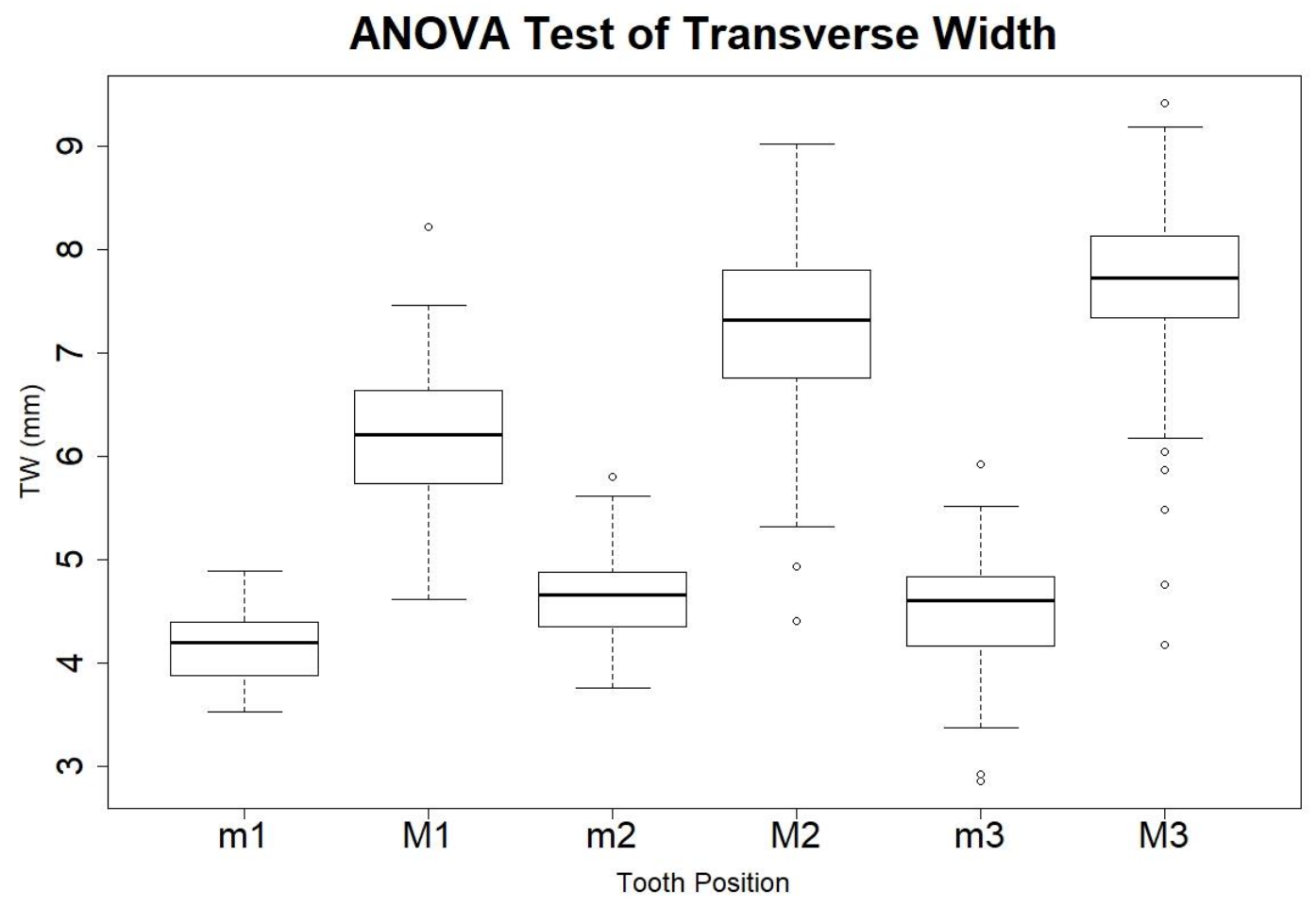

Figure 6. Boxplot of ANOVA results for TW of different tooth positions across all hypertragulids. TW is similar for all lower molars, which is significantly different from the upper molars. 


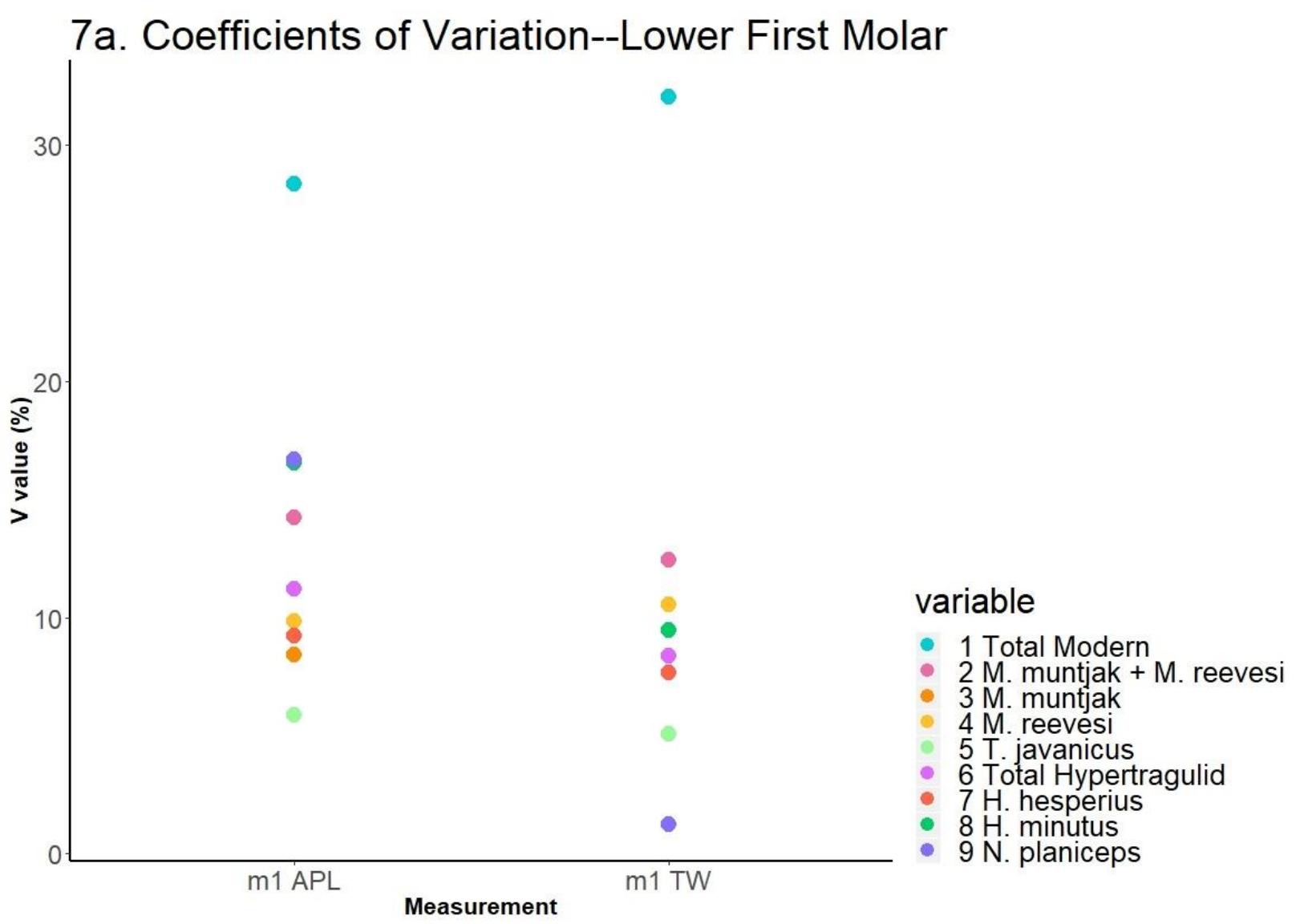

7b. Only Modern--Lower First Molar

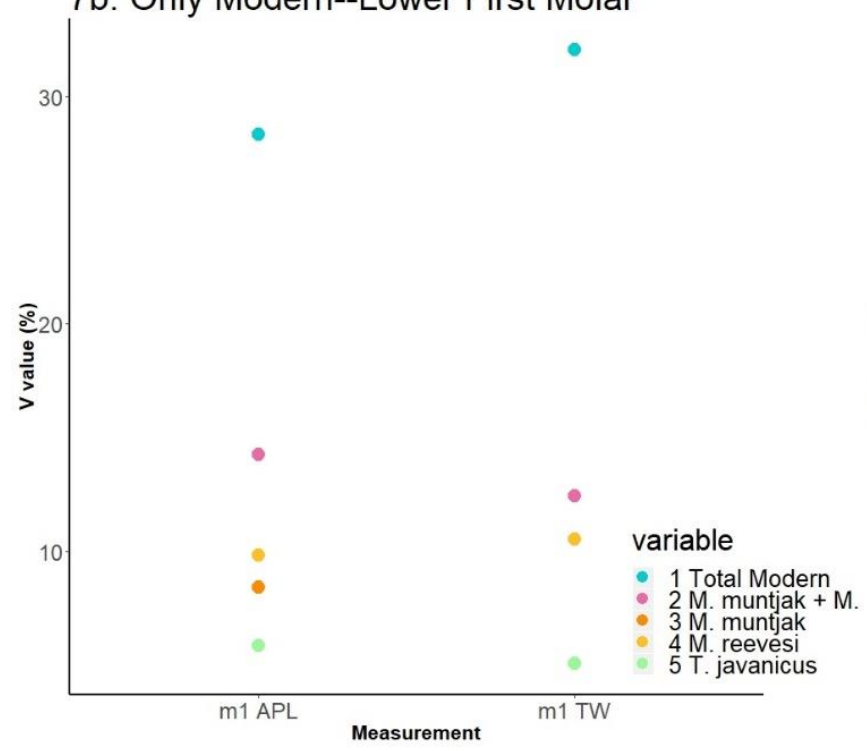

7c. Only Fossil---Lower First Molar

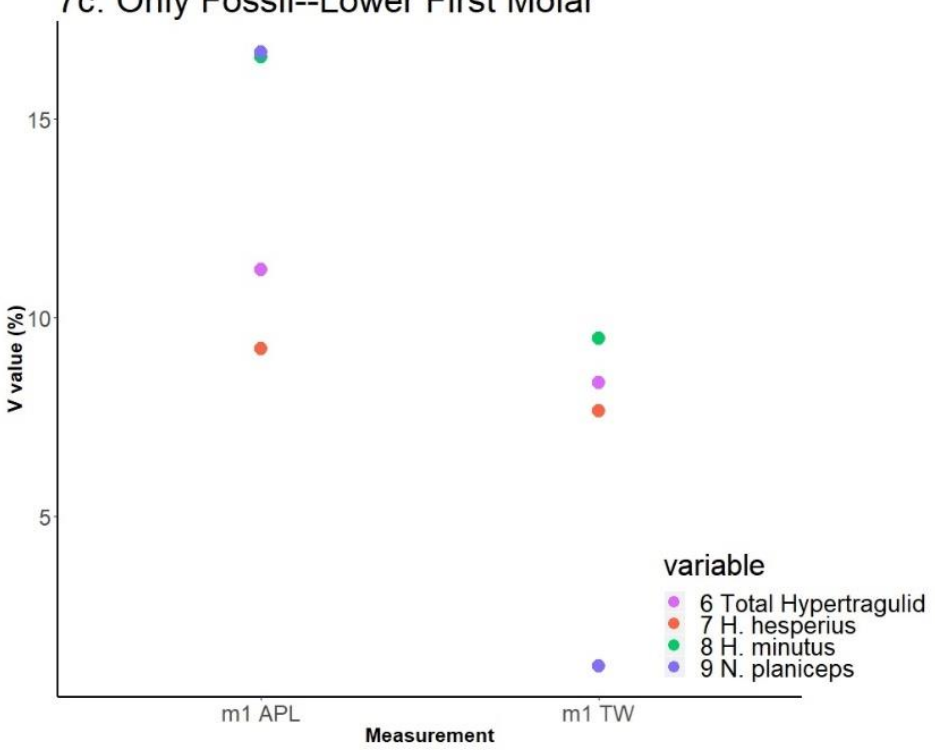

Figure 7a. V values for lower first molar measurements of all modern analogs, all fossil hypertragulid species, as well as combined populations for comparison. Highest value is for the total modern analog population. $7 b$. $V$ values for only modern analogs. 7c. $V$ values for only extinct species. 


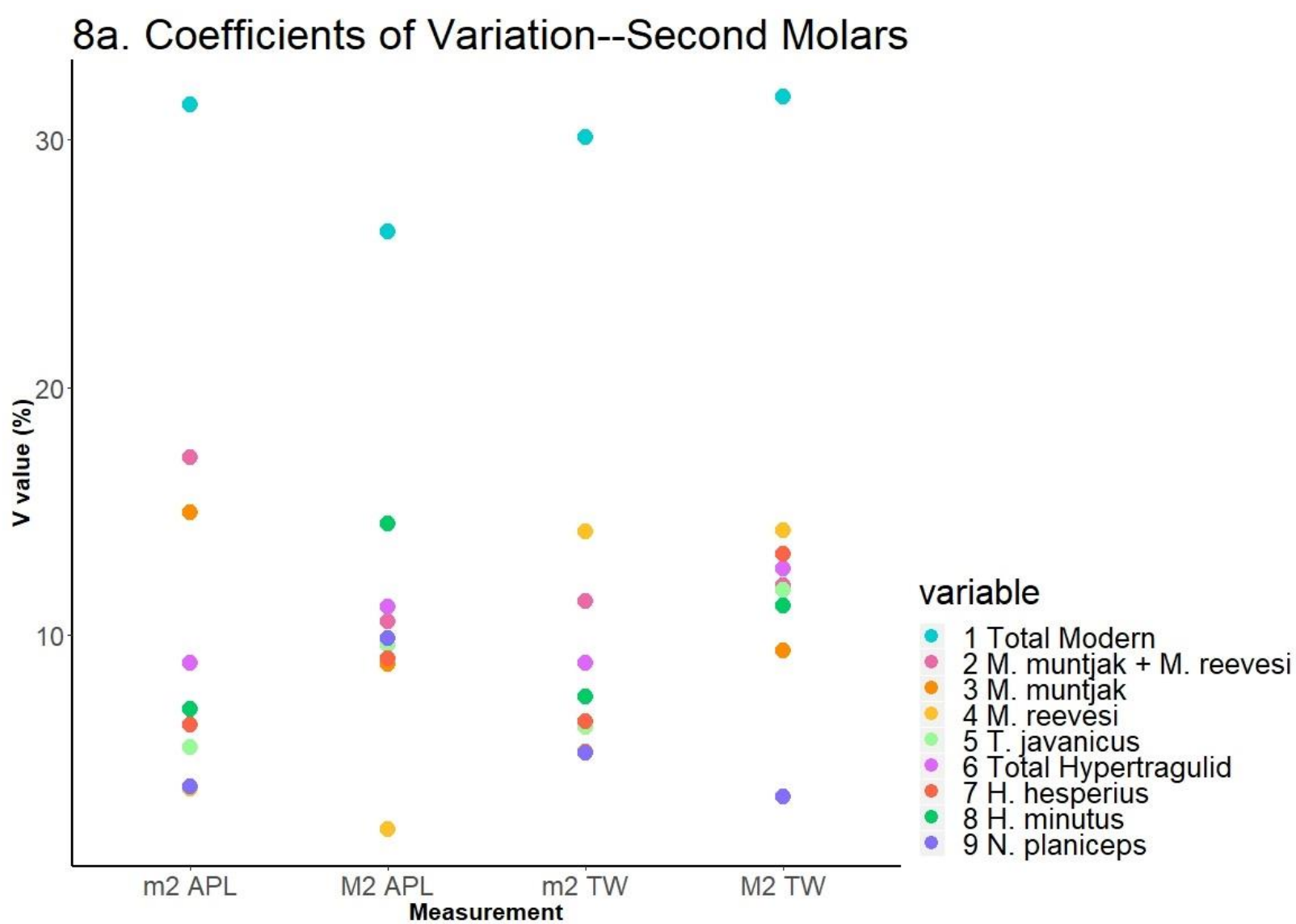

8b. Only Modern--Second Molars
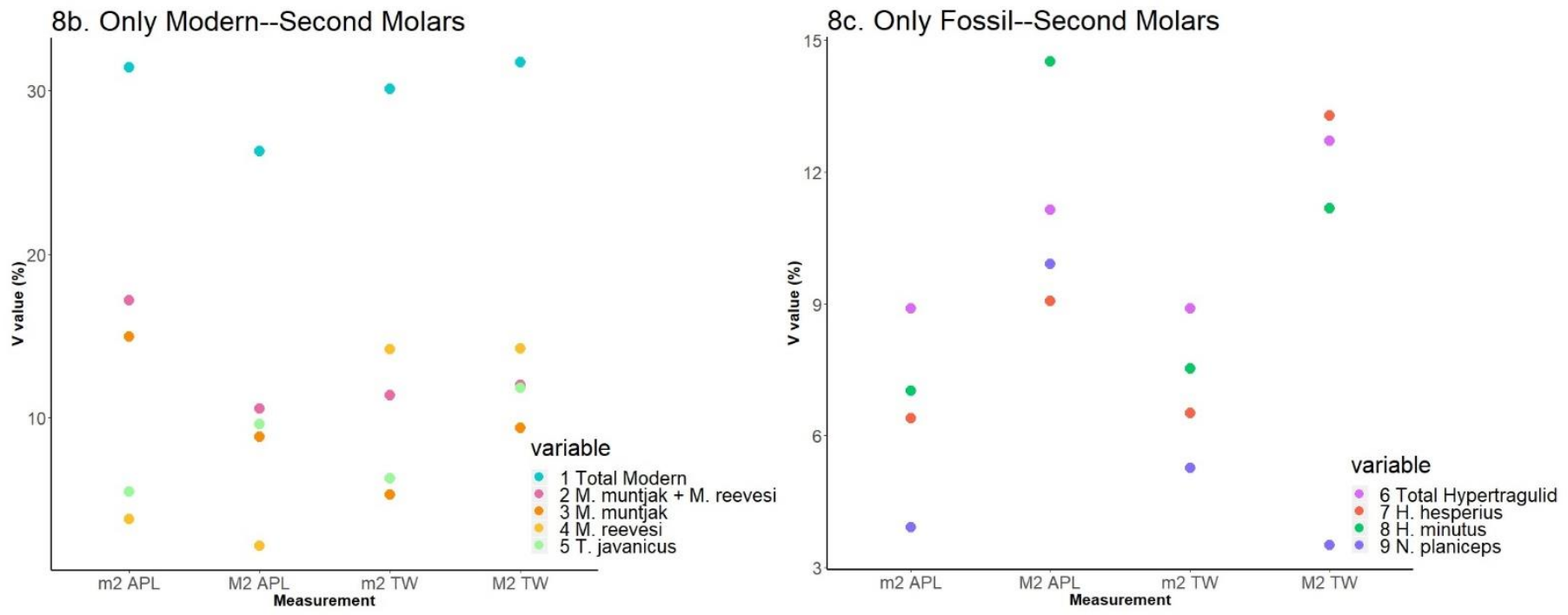

Figure 8a. V values for upper and lower second molar measurements of all modern analogs, all fossil hypertragulid species, as well as combined populations for comparison. Highest value is for the total modern analog population. $8 b$. $V$ values for only modern analogs. 8c. $V$ values for only extinct species. 
Table 4. V values and V equality p-values for all tooth position measurements of the total hypertragulid population as compared to the modern Muntiacus muntjak population. Bold p-value denotes significant difference in V values, where $p<0.05$.

\begin{tabular}{|c|c|c|c|c|c|c|}
\hline & M1 APL & m1 APL & M2 APL & $\mathrm{m} 2 \mathrm{APL}$ & M3 APL & m3 APL \\
\hline Fossil Hypertragulid $V$ & 11.5181766 & 11.2226980 & 11.1426880 & 8.89243245 & 11.0692139 & 13.924553175 \\
\hline Modern $M$. muntjak $V$ & 12.5114072 & 8.4407769 & 8.8489405 & 14.96139669 & 10.7185901 & 5.358249526 \\
\hline Asymptotic $p$-value & 0.7000734 & 0.8909070 & 0.4937135 & 0.02626072 & 0.3758709 & 0.021665986 \\
\hline Modified SLRT $p$-value & 0.8553496 & 0.8716533 & 0.3737391 & 0.08548824 & 0.2912266 & 0.008271829 \\
\hline & M1 TW & $\mathrm{m} 1 \mathrm{TW}$ & $\mathrm{M} 2 \mathrm{TW}$ & $\mathrm{m} 2 \mathrm{TW}$ & M3 TW & $\mathrm{m} 3 \mathrm{TW}$ \\
\hline Fossil Hypertragulid $V$ & 11.830448 & 8.3699800 & 12.7041264 & 8.89243245 & 13.6722155 & 13.1002201 \\
\hline Modern $M$. muntjak $V$ & 10.262837 & 5.0651729 & 9.3829699 & 5.29238168 & 11.3184878 & 8.0713118 \\
\hline Asymptotic $p$-value & 0.532573 & 0.4412137 & 0.3840301 & 0.13751851 & 0.3758709 & 0.1645751 \\
\hline Modified SLRT $p$-value & 0.483879 & 0.3690194 & 0.2995962 & 0.09456959 & 0.3078046 & 0.1127612 \\
\hline
\end{tabular}




\section{Astragali}

The Principal Components Analysis was done on 35 undamaged hypertragulid astragali. The first principal component (PC1) accounts for $75.35 \%$ of the variation but when combined with the second principal component (PC2) brings the total variation explained up to $83.77 \%$.

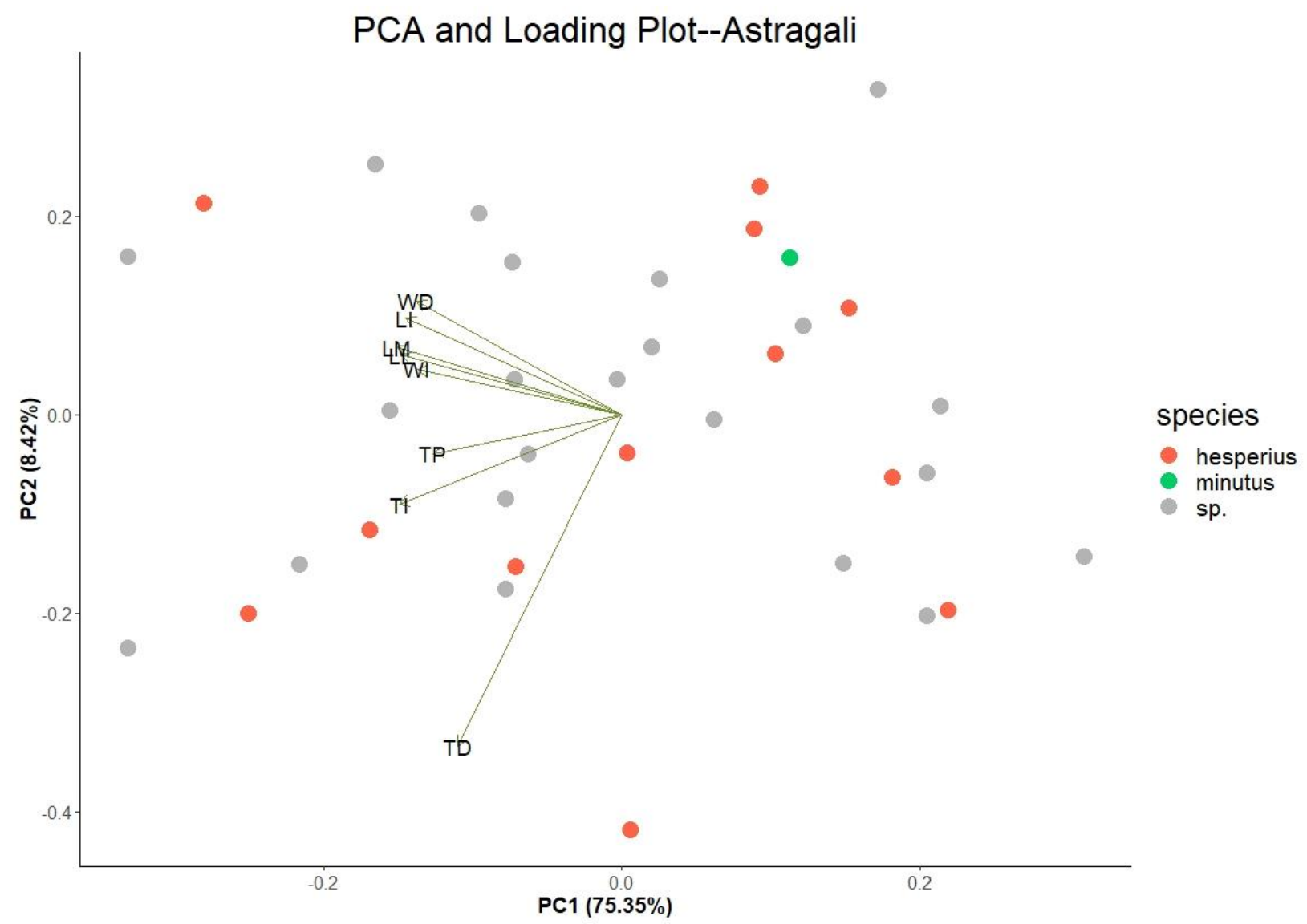

Figure 9. PCA and loading plot of whole astragali. Different individuals are labeled as points, with the first two principal components as axes. Correlated dimensions are grouped closest together, and unrelated dimensions are at right angles.

The loading plot of astragali dimensions in Figure 9 shows a strong correlation between: distal width and intermediate length; medial length, lateral length, and intermediate width; proximal thickness and intermediate thickness; and distal thickness was unrelated to the other components. I used this correlation of dimensions to select the four primary dimensions for analysis: intermediate length (LI), intermediate width (WI), intermediate thickness (TI), and distal thickness (TD). I then added partially damaged astragali where these four dimensions were intact to my dataset, bringing the total sample up to 53. This group contained 31 unidentified hypertragulid astragali, $19 \mathrm{H}$. hesperius, two $\mathrm{H}$. minutus, and one identified $N$. planiceps astragali, the measurements of which are shown in Figure 10. 

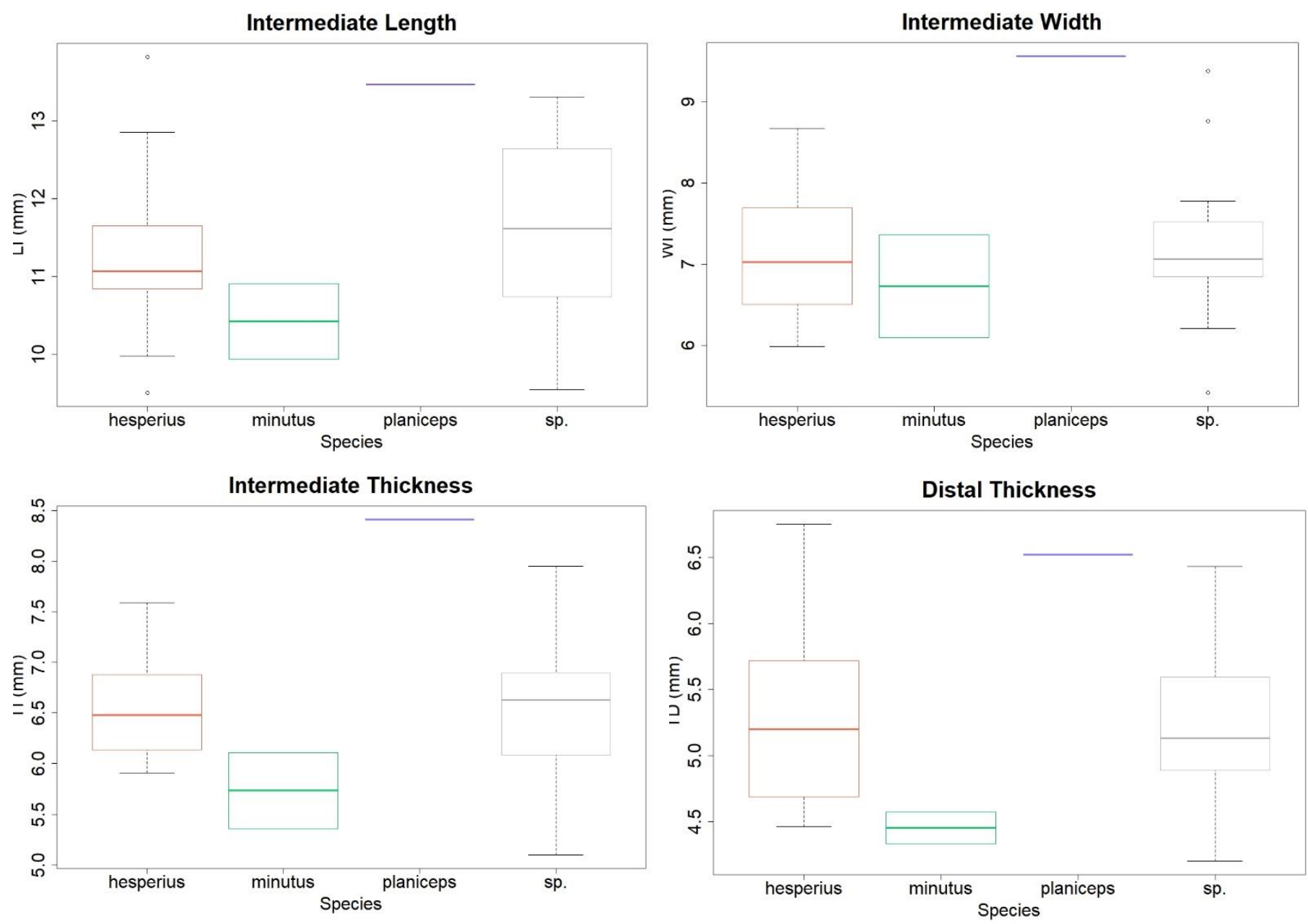

Figure 10. Boxplots of four chosen astragali measurements, with the y-axis showing millimeters and the x-axis sorted according to species designation. The single N. planiceps specimen is recorded as a line.

Table 5. V values and $V$ equality p-values for selected astragali dimensions of fossil hypertragulids and the modern T. javanicus population

\begin{tabular}{|l|l|l|l|l|}
\hline & LI & WI & TI & TD \\
\hline Fossil Hypertragulid population $V$ & 9.540501 & 11.38828 & 10.14137 & 11.66088 \\
\hline Modern $T$. javanicus $V$ & 11.526675 & 14.34874 & 11.69205 & 16.73888 \\
\hline Asymptotic $p$-value & 0.4796086 & 0.3821922 & 0.6016645 & 0.1518182 \\
\hline Modified SLRT $p$-value & 0.6074324 & 0.5786480 & 0.2737831 & 0.2737831 \\
\hline
\end{tabular}


Table 5 displays $V$ values and $p$-values of $V$ equality tests for each of the astragali dimensions examined. There is no significant difference in variation for any of the four principal dimensions between the extinct and extant species, with no $p$-value for either test below 0.05 .

\section{DISCUSSION}

Among the eight dental measurements examined in this study, only one measurement (m3 APL) showed significant variation between the hypertragulid population of the John Day Basin and a single modern species. My examination of modern artiodactyl dentition illustrated that variation follows an expected progression of increasing $V$ values as the taxonomic group broadened, seen in both Table 1 and Figures $7 \& 8$, but to confirm this pattern the analysis needs to be extended to cover as many tooth positions as possible. The variation of a single species being doubly accounted for in the total population likely explains the one exception of modern analogs not varying significantly. However, the hypertragulid population that was thought to contain three separate species of two different genera has a much lower $V$ than expected-if the observed pattern in a modern group of three species of two genera holds true, the $V$ value should be greater, and there should be a distinguishable variation between the total population, one genus, and individual species. Instead the predominantly non-significant variability between the total hypertragulid population and individual hypertragulid species supports the null hypothesis that only one species of hypertragulid was present in the John Day Basin, and rejects the alternate hypotheses.

The examination of the astragali, and the consequential statistical lack of variation between extinct and extant populations, seems to further confirm this hypothesis of a single species. This could simply reflect the limited sample size of identified $H$. minutus and $N$. planiceps astragalus specimens. The variance seen in the group of specimens unidentified at the species level (Figure 10 ) is potentially wide enough to be more representative of the population than I can confirm. Lack of associated craniodental material with these astragali means that no better designation can be reached at this point for these specimens, and further data would be required to strengthen the support for the single-species hypothesis. Additionally, a more thorough analysis of astragali in modern small ruminant taxa, similar to the one conducted with dentition in this study, is necessary to determine whether astragali variability is a reasonable premise to separate these species. 
Taxonomic over-splitting is likely responsible for the the discrepancy between the levels of variation seen in this study and the initial description of three species. A normal distribution of variation in a single-species population can be split somewhat arbitrarily, and new species can be designated based on only a small subset of the actual total population. The work done in this study reveals a lack of statistical support for these designations, but there are many other ways to designate species besides dentition and postcranial characters, most notably qualitative cranial characters (Famoso, 2017)

While a preliminary study of the hypertragulids used a Shapiro-Wilks test on upper first molars to search for multiple means in the population, this step was omitted in this study given that only one mean was found (Famoso, 2018). However, modern mouse-deer, chevrotains, and muntjacs all exhibit sexual dimorphism - tragulid males are smaller, but possess larger canine tusks (Janis, 1984), while muntjak males are larger with a larger upper canine tusk than females (Janis, 1990). Since astragali dimensions are a known indicator of body size in artiodactyls (Martinez \& Sudre, 1995; DeGusta \& Vrba, 2003; Davis \& McHorse, 2013) future research should account for the possibility of sexually dimorphic astragali dimensions and sort variation in these two separate populations accordingly.

\section{ACKNOWLEDGEMENTS}

First and foremost, I thank my advisors N. Famoso and A. Streig for their invaluable instruction, advice, reviews, and overall support. I extend my gratitude to the Portland State University Geology Department, who provided funds and resources to present this work. I would like to thank the National Park Service and the Bureau of Land Management for providing and curating the fossils used in this study, as well as the entire JODA staff for opening their collections to me and their support. I thank C. Janis for providing her invaluable dataset of modern artiodactyl tooth measurements, without whom this research would not be possible, as well as M. EmeryWetherell and E. Davis for their existing published data. Additionally, I would like to thank M. Omura at MCZ for providing long-distance access to the vertebrate collections, and M. Mullon for photographing astragali specimens for me, and E. Biedron and L. Ford for getting me connected to the right people. I thank W. McLaughlin for her advice and discussions on my earliest drafts. I would also like to acknowledge J. Graham-Davis, A. Orr, A. Horst, and R. Levinson for their continued support and revisions of this thesis. 


\section{References}

Cope, D. A., \& Lacy, M. G. (1992). Falsification of a single species hypothesis using the coefficient of variation: a simulation approach. American Journal of Physical Anthropology, 89(3), 359-378.

Davis, E. B., \& Calède, J. J. M. (2012). Extending the utility of artiodactyl postcrania for species-level identifications using multivariate morphometric analyses. Palaeontologia Electronica,15(1); 1A:1-22. https://doi.org/10.26879/260.

Davis, E., \& McHorse, B. (2013). A method for improved identification of postcrania from mammalian fossil assemblages: multivariate discriminant function analysis of camelid astragali. Palaeontologia Electronica, 16(3); 27A:1-15. https://doi.org/10.26879/356.

DeGusta, D., \& Vrba, E. (2003). A method for inferring paleohabitats from the functional morphology of bovid astragali. Journal of Archaeological Science, 30(8), 1009-1022.

Emery-Wetherell, M., \& Davis, E. (2018). Dental measurements do not diagnose modern artiodactyl species: Implications for the systematics of Merycoidodontoidea. Palaeontologia Electronica, 21(2); 23A 1-28. https://doi.org/10.26879/748

Famoso, N. A., Davis, E. B., Samuels, J. X., \& Emery, M. M. (2014, October). Evidence of volcanically induced turnover in mammalian communities of the John Day Basin, Oregon. In 2014 GSA Annual Meeting in Vancouver, British Columbia.

Famoso, N. A. (2017). Statistical analysis of dental variation in the Oligocene equid Miohippus (Mammalia, Perissodactyla) of Oregon. Journal of Paleontology, 91(5), 1060-1068.

Famoso, N. A. (2018). Statistical analysis of dental variation in Oligocene hypertragulids (Mammalia, Artiodactyla) of Oregon. In 2018 Annual Society of Vertebrate Paleontology Meeting in Albuquerque, New Mexico.

Feltz, C. J., \& Miller, G. E. (1996). An asymptotic test for the equality of coefficients of variation from k populations. Statistics in medicine, 15(6), 647-658.

Fisher, R. A. (1928). Statistical methods for research workers. Oxford, England: Stechert. 
Gardner, C. K. (2015). Taxonomic Diversity and Interrelationships of the Hypertragulinae Within the Great Plains Regions of North America (Master's thesis, South Dakota School of Mines and Technology, Rapid City).

Hammer, Ø., \& Harper, D. A. (2008). Paleontological data analysis. John Wiley \& Sons.

Hay, O. P. (1902). Bibliography and catalogue of the fossil Vertebrata of North America (No. 179). US Government Printing Office.

Janis, C. M. (1990). Correlation of cranial and dental variables with dietary preferences in mammals: a comparison of macropodoids and ungulates. Memoirs of the Queensland Museum, 28(1), 349-366.

Lull, R. S. (1922). Primitive Pecora in Yale Museum. American Journal of Science, (20), 111119.

Krishnamoorthy, K., \& Lee, M. (2014). Improved tests for the equality of normal coefficients of variation. Computational Statistics, 29(1-2), 215-232.

Martinez, J. N., \& Sudre, J. (1995). The astragalus of Paleogene artiodactyls: comparative morphology, variability and prediction of body mass. Lethaia, 28(3), 197-209.

Marwick, B., \& Krishnamoorthy, K. (2019) cvequality: Tests for the Equality of Coefficients of Variation from Multiple Groups. R software package version 0.1.3. Retrieved from https://github.com/benmarwick/cvequality, on 01/10/2018

Métais G., \& Vislobokova I. (2007). Basal ruminants. In: Prothero DR, Foss SE, eds. The evolution of artiodactyls. Baltimore: Johns Hopkins University Press, 189-212.

Pearson, K. (1896). VII. Mathematical contributions to the theory of evolution.--III. Regression, heredity, and panmixia. Philosophical Transactions of the Royal Society of London. Series A, containing papers of a mathematical or physical character, (187), 253-318.

R Core Team (2018). R: A language and environment for statistical computing. R Foundation for Statistical Computing, Vienna, Austria. URL https://www.R-project.org/.

Schneider, C. A., Rasband, W. S., \& Eliceiri, K. W. (2012). NIH Image to ImageJ: 25 years of image analysis. Nature methods, 9(7), 671. 
Simpson, G. G., \& Roe, A. (1939). Quantitative zoology: Numerical concepts and methods in the study of recent and fossil animals.

Sinclair, W. J. (1905). New or imperfectly known rodents and ungulates from the John Day Series. University of California Press.

Sokal, R. R., \& Braumann, C. A. (1980). Significance tests for coefficients of variation and variability profiles. Systematic Biology, 29(1), 50-66.

Tang, Y., Horikoshi, M., \& Li, W. (2016). ggfortify: Unified Interface to Visualize Statistical Result of Popular R Packages. The R Journal 8.2 (2016): 478-489.

Tedford, R. H., Albright III, L. B., Barnosky, A. D., Ferrusquia-Villafranca, I., Hunt Jr, R. M., Storer, J. E., ... \& Whistler, D. P. (2004). Mammalian biochronology of the Arikareean through Hemphillian interval (late Oligocene through early Pliocene epochs) In Late Cretaceous and Cenozoic Mammals of North America: Biostratigraphy and Geochronology. Columbia University Press, New York, 169-231.

Vislobokova, I. A. (2001). Evolution and classification of Tragulina (Ruminantia, Artiodactyla). Paleontological Journal, 35(2), S69-S145.

Webb, S. D., \& Taylor, B. E. (1980). The phylogeny of hornless ruminants and a description of the cranium of Archaeomeryx. Bulletin of the AMNH; v. 167, article 3. Retrieved from http://digitallibrary.amnh.org/handle/2246/1042

Wickham, H., François, R., Henry, L., \& Müller, K. (2018). dplyr: A Grammar of Data Manipulation. R package version 0.7.8. https://CRAN.R-project.org/package=dplyr

Woodburne, M. O. (2004). Global events and the North American mammalian biochronology In Late Cretaceous and Cenozoic mammals of North America: biostratigraphy and geochronology. Columbia University Press, New York, 315-343. 